\title{
IRISH STUDIES IN SPAIN - 2018
}

\section{María Losada Friend (ed.)}

Copyright (c) 2019 by the authors. This text may be archived and redistributed both in electronic form and in hard copy, provided that the author and journal are properly cited and no fee is charged for access.

\section{Introduction}

María Losada Friend 234

Giving Shape to the Moment. The Art of Mary O'Donnel: Poet, Novelist and Short Story Writer.

María Elena Jaime de Pablos, ed.

Asier Altuna-García de Salazar

Voice and Discourse in the Irish Context.

Diana Villanueva Romero, Carolina P. Amador-Moreno and Manuel Sánchez García, eds.

José $\mathrm{M}^{\mathrm{a}}$ Tejedor-Cabrera.

Irishness on the Margins: Minority and Dissident Identities.

Pilar Villar-Argáiz, ed.

Auxiliadora Pérez Vides

Un almuerzo literario y otros cuentos.

Éilís Ní Dhuibhne. (Translated by Luz Mar González-Arias)

Llüisa Schlesier Corrales

Desnudo.

Nuala Ní Chonchúir. (Translated by Máximo Aláez Corral)

Antonio Rivero Taravillo 
Introduction

\section{María Losada-Friend}

To summarize the news about Ireland that have reached Spain in 2018 requires at least a weather metaphor to explain the various turmoils and breezes of change that have shaken the country. At the beginning of the year Ireland was isolated by wild winds of the storm Emma that left high accumulations of snow and by the end of June the Irish population experimented the highest temperatures in Ireland since 1976. Similar turbulences in political, social or religious areas prove the country's coping with conflicts and issues in this decade of the $21^{\text {st }}$ century. Contrasts and clashes prove its struggle, movement and progress.

On the one hand, campaigns against Ireland's housing crisis along the year have walked together with Project Ireland 2040, a plan that hopes to spread economic development across a country which expects a popular expansion of at least one million people. Besides, and like the rest of other states in Europe, Ireland has been immersed in the debate regarding a potential no-deal Brexit, which obviously will affect its relations with the UK, as it witnesses the increasing number of Irish passports issued due to the fear of Brexit consequences.

On the other hand, the debate and people's decision around the referendum on the repealing of the Eighth Amendement of the Constitution Act 1983 has set the regulation of termination of the Pregnancy Bill, allowing for abortion legislation in the Republic of Ireland. Besides, the Papal visit in Dublin of two days in August gave way to questions and reflections on the role of the Catholic Church in an Ireland that is going under the process of shattering consciences, exposing truths and acknowledging the pain and shame of clerical and institutional abuses. All this comes at a time in which simultaneously voices from the 220 survivors of Magdalene Laundries have been heard. Received in a special reception hosted by President Higgins in June at Áras an Uachtaráin, and coming from Ireland, the UK, the US and Australia, they were brought together for the first time. Other small but significant signs of change such as the passing of the legislation procedures to allow the sale of alcohol in Good Fridays after ninety years, or the decision to remove the word "blasphemy" from the Irish Constitution indicate slow but pertinent transformations in a modernised country.

We also witnessed the re-election of Michael D. Higgins as President of the Republic of Ireland for a second term in October. The so-called "poet president" made a significant speech defending the value of dialogue stating: "words matter, words can hurt, words can heal, words can empower, words can divide". Assuming transformation in Ireland, he envisioned a country that would stand "equal and together", with "strong, sustainable communities, sharing history, shaping the future", and forcefully affirmed: "Ireland's voice matters".

One quick glance at changes in sports shows that in November both hurling and camogie were officially recognized by UNESCO as protected cultural activities. This is not only good news for the relevance of Irish sports but also because it proves that active participation of female athletes is an acknowledged reality in Ireland. As a good example, Ireland's women's hockey team was to be congratulated after the good results at the Hockey World Cup in August. With a silver medal, they have been the first Irish team to get to a senior world final in any field sport.

In the literary side, Anna Burns was awarded the Man Booker Prize 2018 for her novel Milkman. She has become thus the first writer from Northern Ireland ever to do so after three other Irish authors in the past: Roddy Doyle (1993), John Banville (2005) and Anne Enright (2007). Ending with a nostalgic note, Ireland has sadly said goodbye to Dolores O'Riordan, the beautiful voice of the Cranberries who made us feel Ireland deep in our hearts. 
The year in review also proves that 2018 has been a prolific one regarding the numerous events and publications related to Ireland in Spain. A frenzy for cultural and academic activities seems to have spread all over our country.

In February 2018, the Irish Itinerary sponsored by EFACIS (European Federation of Associations and Centres of Irish Studies) took place at the Universities of Granada and La Rioja, with the relevant participation of two keynote artists in the Irish contemporary panorama: playwright Marina Carr and Pat Boran, poet, editor of Dedalus Press and presenter of "The Poetry Programme" in RTÉ (Raidió Teilifís Éireann). The Itinerary opened at the Center for Irish Studies at the University of Granada, under the direction of Pilar Villar Argáiz and Encarnación Hidalgo Tenorio. The International Seminar organized here (already consolidated in its 3rd Edition) also counted on the participation of prestigious documentarymaker Maurice H. Fitzpatrick, the Irish traditional music band Gan Ainm, and several lecturers specialized in the field of Irish studies, coming from other universities in Spain. Simultaneously, Melania Terrazas and Jonatan González organized the seminar entitled Trauma and Identity in Contemporary Irish Literature and Film, at the Center of Irish Studies BANNA/BOND. Later in May, the University of La Rioja also hosted the itinerary exhibition The Irish in Latin America as part of the scientific seminar The Irish in LatinAmerica: History and Culture. It was a great opportunity to prove the strong links that Irish Studies in Latin America and Spain share, promoting exchanges and projects of great interest. With 26 posters the exhibition showed the convergence of Ireland and Latin American countries in their struggle for independence, regarding issues of colonization and revolution.

One of the best annual events, the 17th AEDEI Conference entitled this year "Ecofictions Irish Studies", took place at the University of Santiago de Compostela (31 May-1 June). It proved the interest for updating Irish Studies in terms of ecological criticism. Various papers reflected upon the relevance and concern for the Irish landscape and environment. Academic experts such as Elke D'Hoker (UK Leuven, Belgium), Anne Fogarty (UCD) and well-known writers as Sara Baume and Celia de Fréine were selected guests.

Traditional Irish holidays were celebrated around Spain with joy leaving memorable traces. St Patrick's Day in March framed the academic seminar at the University of Almería (II Jornadas de Estudios Irlandeses) symbolically enlightening in green emblematic fountains in the city and monuments as the Alcazaba and the Stadium of the Mediterranean Games. Besides, the annual traditional Bloomsday was celebrated in the Ateneo of Madrid organized by the Blommsday Society with readings from Joyce and live music from Irish group Púca Og. Cáceres also contributed to the Irish touch in the celebration of the $15^{\text {th }}$ edition of the Irish Fleadh (25-28 October), one of the most important festivals of folk music in Europe with a programme focused in traditional Irish music. Simultaneously in October, the festival Creative-Connexions Ireland at Sitges Live 2018 embraced music, dancing and poetry with this year's special homage "Thomas Moore-Reawakened".

In addition, the Pearse Hutchinson Exhibition from the University of Maynooth Library was hosted by the University of Coruña in October. It proved Huthinson's (19272012) connections with Spain and his valuable task as translator of poems by Spanish, Galician and Catalan authors. Precisely in that same line, AEDEI member Verónica Membrive (University of Almeria) was awarded with the prize "George Campbell" granted by the Aula María Zambrano-Transatlantic Studies (University of Málaga) for her research on Hutchinson and Aidan Higgins.

Another good sign of the good health of academic relations between Ireland and Spain became obvious in November with the presentation of Diary of Crosses Green (Francis Boutle Publishers, 2018), Keith Payne's translation into English of Martin Veiga's book of poems. It proved the many points in contact between the Irish Center of Galician Studies at 
the UCC and the University of Vigo and the cross disciplinary nature of poetical IrishGalician exchanges.

Our colleague Anne Mary Murphy at the Embassy of Ireland in Spain has kept us updated with many other cultural events related to Ireland along the year. Among others, September marked the $400^{\text {th }}$ anniversary of the death of Irish leader Donal Cam O'Sullivan Beare in Madrid, where talks and tours analysed the Spanish links with the Irish community during the $17^{\text {th }}$ century. Irish poetry boomed over the summer in Spain: The Poetry Festival in Vigo counted with the participation of Ana Crowe Serrano, Irish born poet and translator. Similarly, the Poetry Festival in Soria united the voices of Irish poets Moya Cannon and Mary O'Malley, and in July, the 8th Festival Catalunya Celta embraced musicians, singers and dancers like Mossie Martin, Oisín MacDiarmada, Samantha Harvey and Séamus Begley.

The Irish radio programme in Spain ("Live on Eire") which broadcasts daily on Talk Radio Europe has offered debates and updates on Brexit and Ireland and interesting talks as the one with former Spanish Ambassador to Ireland, José Antonio Yturriaga, or with AEDEI colleague Patricia Trainor from Belfast on the experience on her years of teaching Irish literature at the University of Malaga.

Finally, Ireland was appointed guest country at the Book Fair in Seville in May. Small green shamrocks in the programme marked the profusion of talks, round tables and presentations of books related to Irish cultural issues. The special presence of ambassador Síle Maguire and author Lisa McInerney (Baileys Women Prize for Fiction 2017) inaugurated the many activities about Ireland scattered in the Fair. McInerney presented her new novel The Blood Miracles (2018) and its Spanish translation and she discussed tradition and new tendencies on Irish narratives. There was also a homage to Edna O'Brien, four short documentaries on W.B.Yeats and several round tables ("Three incursions into Irish history and literature", "Literature by women" and "From James Joyce to Flann O'Brien and Other Weeds").

To round up with the academic contributions, the list of publications by AEDEI members recollected by María Jesús Lorenzo Modia for the annual IASIL bibliography provides a useful and interesting insight of the good work of on Irish Studies from Spain. Similarly, the journal Estudios Irlandeses is to be congratulated as two numbers saw the light in 2018: Number 13:1 and the special issue guest edited by Melania Terrazas Gallego, Gender Issues in Contemporary Irish Literature (13:2). To this, we add five exhaustive reviews by AEDEI members and expert colleagues included below. They cover a translation of Nuala Ní Chonchúir's Nude published at the end of 2017, and four published works from 2018, three edited collections and the translation of Éilís Ní Dhuibhne's volume of short stories.

María Losada Friend is a senior lecturer in the English Department at the University of Huelva, presently teaching at the University Pablo de Olavide (Seville). A long standing AEDEI member, she was the President of the Organizing Committee of the 11th AEDEI Conference at the University of Huelva (2012) and co-organizer of the EFACIS Conference at the University of Seville (2007). Her main area of research is Comparative Literature and studies exchanges between Spanish, English, Irish and American narrative discourses, with published works on Oliver Goldsmith, Edna O'Brien and James Joyce. She coordinated Teaching Ireland: New Didactic Approaches to Cultural, Linguistic and Literary Issues (2010) and co-edited Dreaming the Future: New Horizons/Old Barriers in 21st-Century Ireland- Irish Studies in Europe, vol.3 (2011) and Words of Crisis/Crisis of Words: Ireland and the Representation of Critical Times (2016). 
mlosfri@upo.es

Giving Shape to the Moment. The Art of Mary O'Donnell: Poet, Novelist and Short Story Writer. (Series Reimagining Ireland, vol. 88)

Edited by María Elena Jaime de Pablos.

Oxford: Peter Lang, 2018. 218 pp.

ISBN: 978-1-78874-403-4

Reviewer: Asier Altuna-García de Salazar (University of Deusto, Spain)

María Elena Jaime de Pablos's edited collection Giving Shape to the Moment: The Art of Mary O'Donnell, Poet, Novelist and Short-Story Writer constitutes the first book-length critical volume on this important Irish figure. It represents a much needed, illuminating and insightful critical approach to Mary O'Donnell, who since the beginning of 1990 has published widely in the three genres referred to by the title of this critical volume. This splendid academic study presents an adequate rationale as it comprises 6 essays dealing with O'Donnell's fiction, poetry, short fiction and cultural output. These are followed by a recent interview with the Irish author, a new short story by O'Donnell and a comprehensive bibliography of primary and secondary sources. The latter will meet the needs of any reader, critic and scholar on Mary O'Donnell. A critical approach to Mary O'Donnell was much needed and this volume will make an important contribution to scholarship in Irish Studies. The publication of the volume as part of Peter Lang's Reimagining Ireland series confirms this fact. There have been some critical articles in journals and chapters in other volumes on this Irish author, but no comprehensive volume on this author has appeared yet. Therefore, this volume will find an important space within the critical studies on today's Irish authors. As this volume shows, Mary O'Donnell's literary and critical production has always engaged with themes, tropes and topics that delve into literary experimentation, preoccupation with human issues, gender and a pluralist Ireland. Her literary innovation has always been met with an appreciation of that which is deeply human. Accordingly, the volume has the ultimate objective to produce a comprehensive academic approach to O'Donnell's work that was pending. This is difficult to understand as she has been considered an important Irish author with a body of work that features seven collections of poetry, four novels, two collections of short stories and many radio contributions, reviews and academic essays. This book constitutes, thus, a salient achievement. The volume is well written and its structure follows not only a chronological stance but is clearly divided into the main genres used by Mary O'Donnell. The international scholars who participate in this volume are known for their expertise on Irish women's writing and have important impact contributions on the field. The six chapters in the present volume could be read separately as the intention behind reveals a clear interest in offering a succinct analysis of Mary O'Donnell's writings. This important academic work pays homage to a writer who has always proved to blend artistic and literary mastery with ideas of humanism, social justice, feminism and truth.

As stated above, this volume contains a number of critical essays of academic excellence that are followed by an interview and a new short story by Mary O'Donnell. The final chapter includes a complete bibliography on a myriad of primary and secondary sources that deal with O'Donnell's production. The volume begins with a wonderful preface by Éilís Ní Dhuibhne, who claims that Mary O'Donnell is more than what the word "writer" 
designates and believes O'Donnell is a "poet", and not a writer of poetry. The word "poet" captures the real essence of Mary O'Donnell. Ní Dhuibhne traces the beginnings of O'Donnell's production and sets it against that backdrop of Dublin's literary and publishing world. For Ní Dhuibhne, O'Donnell excels in artistic and human frankness, engagement and honesty. O'Donnell engages with life, society and Ireland from different but related perspectives. Ní Dhuibhne praises this critical and academic collection and thanks the editor, contributors and all those "Irish friends in Spain" for honouring Mary O'Donnell with the volume. The editor to the volume, María Elena Jaime de Pablos introduces the whole collection and reminds the reader of the original idea for the volume, one of the annual international AEDEI Conferences, this time held at the University of Alcalá, Spain in May 2006. Since its creation The Spanish Association for Irish Studies (AEDEI) has catered for academic excellence on Irish Studies and its members have always shown a passion for Ireland and her artists. Mary O'Donnell was one of the writers invited to this conference and after her enticing reading the editor to this volume came with idea to produce a critical study on O'Donnell's works and achievements. Jaime de Pablos introduces the contributors and explains what the contents of their illuminating chapters are. That only one male critic appears in the collection should raise, according to Jaime de Pablos, a concern for how responses to female writers appear on publications. This concern to place critical approaches to female Irish writers is also extended by the editor of this volume to Mary O'Donnell's place within the Irish literary canon. For many, she has been described as a feminist writer, a liminal writer, a complex writer that has not accommodated within a clear place in her own culture. But, as the editor claims, O'Donnell's range of themes, topics and literary experimentation cover many of today's issues worldwide and, especially, in Ireland.

The first academic chapter by Mary Pierse already contextualizes Mary O'Donnell's works within an Irish literary scene that was male-dominated. O'Donnell's first works must be seen, for Pierse, together with a flowering of female production that was starting to find its voice. What all these female authors achieved in Ireland was ground-breaking, as these female Irish writers started to give their insights and views to social, economic, political and cultural issues in Ireland from an inclusive perspective that also had women at its centre. Mary Pierse correctly examines the options undertaken by Mary O'Donnell with her first works and how her writing partook of a common trend in Ireland to contest a long-established gender bias.

The second chapter of this volume is an outstanding examination of Mary O'Donnell's essays in academic publications, shorter articles and contributions to the media, especially the radio. Manuela Palacios succinctly traces many of these contributions and reads them from the perspective of their value as representative of O'Donnell's interest in culture at large, and Irish in particular. For Palacios, O'Donnell's academic production not only positions O'Donnell as an author who also examines her own creative process, but, rather, as an author who questions with an inquisitive mind, many of the contemporary issues that occurred within the Irish literary discourse. Palacios claims the importance of Mary O'Donnell not only as a poet but also as an intellectual and cultural critic that comprehensibly covers Ireland's culture with her works and views. Pilar Villar-Argáiz offers a brilliant approach to Mary O'Donnell's poetic oeuvre. In her academic overview of O'Donnell's poems, Villar-Argáiz scrutinizes the main tenets, tropes, themes, stylistic explorations and features of O'Donnell's poetic work. This detailed chapter brings to light a concern for O'Donnell's needed inclusion in new analytical frames that see her as a poet of diversity, multiculturalism and even ecology in today's Ireland. The next chapter of the collection, by Eibhear Walshe, delves into O'Donnell's fictional world. Although O'Donnell has only produced four novels to date, Walshe claims that these should be read within a discourse that defines a new Ireland that is in constant change and adaptation. For O'Donnell, Ireland should find its place within a Europeanised liberal society. This view has been represented by O'Donnell in her fictional 
works in terms of exploration, change, dislocation and adaptation to a new setting that is still transforming Ireland. María Elena Jaime de Pablos approaches O'Donnell's two collections of short stories and her short narrative production. For Jaime de Pablos, O'Donnell does not shy away from facing cultural critique. Her short prose tackles hypocrisy and directly engages with questions on many issues at stake in Ireland. Jaime de Pablos brilliantly examines how the use of the "mask" by O'Donnell symbolizes a suppression of individual responsibility against social, political, economic, communal and personal problems in today's world that constantly find representation in her short fiction. Giovanna Tallone engages magnificently with O'Donnell's position as an artist who is not only concerned with language and words. O'Donnell has often approached the role of the artist in today's Ireland. O'Donnell has repeatedly shown an interest in the creative process, both her own and that of other artists. This has helped her in understanding experimentation and strategy in writing. The volume ends with an engaging and thought-provoking interview with Mary O'Donnell by Anne Fogarty. Fogarty traces back O'Donnell's artistic beginnings and places her in a discourse of today's Ireland, always hinting at O'Donnell's next writing to come. Mary O'Donnell herself contributes with a short story, as yet uncollected, and winner of the Fish International Short Story Award in 2010.

All in all, María Elena Jaime de Pablos's edited collection Giving Shape to the Moment: The Art of Mary O'Donnell, Poet, Novelist and Short-Story Writer constitutes, thus, a detailed, illuminating, comprehensive and insightful full-length publication on the works of Mary O'Donnell that will help lovers of this Irish author's writings approach her poetry, fiction, short-fiction and academic writings with a new light and fresh perspective. For all the contributors to this academic volume, Mary O'Donnell is a clear representative of contemporary Irish writing who establishes a dialogue between art, the literary form and society at large in a new way. The volume's academic depth makes this study an excellent, clear and definitive critical exemplar of how Mary O'Donnell's works and her take on the issues that surround her in today's world and Ireland were in much need of scholarly assessment.

Asier Altuna-García de Salazar is Chairperson of the Spanish Association for Irish Studies (AEDEI), Associate Professor in English and Irish Studies and Head of the Department of Modern Languages and Basque Studies at the University of Deusto, Bilbao. A former Director of the Erasmus Mundus Master of Arts in Euroculture, his publications include articles on 19th century Spain and the Basque Country in Irish writing and multicultural, transcultural and Celtic Tiger Ireland and literature. He has co-edited Re-Writing Boundaries: Critical Approaches in Irish Studies (2007), New Perspectives on James Joyce: Ignatius Loyola, make haste to help me! (2009), Rethinking Citizenship: New Voices in Euroculture (2013) and Ireland and Dysfunction: Critical Explorations in Literature and Film (2017).

asier.altuna@deusto.es

Voice and Discourse in the Irish Context.

Edited by Diana Villanueva Romero, Carolina P. Amador-Moreno and Manuel Sánchez García.

Cham: Palgrave Macmillan, 2018. 294 pp.

ISBN: 978-3-319-66028-8

Reviewer: José Ma Tejedor-Cabrera (University of Seville, Spain) 
Case-studies volumes are always welcome because they open new areas of analysis and forward conclusions that clear the way in the bog land that knowledge and interpretation often conform today. The first half of this enticing and stimulating approach to voice and discourse in Ireland exploits corpus linguistics not as a goal in itself but as a means to further sociolinguistic and cultural studies. The reader is thus happily not beleaguered with infinite lists of data and, while conclusions are provisional and tentative, they open new spaces for both the study of larger corpora and the discussion of new findings. The second half develops critical approaches to literary texts and, as usual with literary criticism, conclusions are suggestive rather than final but thought-provoking and inspiring, especially the chapters by José Francisco Fernández and Teresa Casal, that stand out among the rest for their extraordinary quality.

The book opens with a serious but relenting study by Elaine Vaughan and Máiréad Moriarty, "Voicing the 'Knacker': Analysing the Comedy of the Rubberbandits," the result of the evaluation of a fairly complete corpus of linguistic data comprising the performances, tweeter feeds, prank calls, recorded music, TV sketches, commentaries, meta-performances and metacommentaries (including printed and on-line articles, miscellanea comments on the YouTube clips and their responses) by and about the Limerick based comic pair the Rubberbandits. The result of this use of the LCIE, the Limerick Corpus of Irish English, as a comparative, reference corpus allows the authors to discuss how the Rubberbandits parody and lampoon the discourse of the Limerick knacker as a social construct and to dig into the comic duo's linguistic consciousness. Beyond punctual annotations commenting, for instance, on what the work "yurt" may (not) mean, the chapter calls attention to the "socio-political code-switching of voices" (32) through the stylization of the language of the knacker that the Rubberbandits turn into humour and satire, thus empowering a marginalized Limerick (Irish) English accent that challenges dominant ideologies.

Making use of an also impressive corpus, C.P. Amador-Moreno and A. O'Keeffe analyse five different types of discourse (intimate, socialising, professional, transactional and pedagogical) plus a large historical literary corpus with the help of digital tools to provide a qualitative approach to the resulting data in their "He's After Getting Up a Load of Wind: A Corpus-Based Exploration of be + after $+V$-ing Constructions in Spoken and Written Corpora". While the larger sections of the chapter are necessarily descriptive, the authors contend that the perfective construction of Irish English "be+after $+\mathrm{V}$-ing" contains an "inherent element of modality" that has "gone unnoticed so far" (59) and that it also bears and additional emotional and vivid character, while its high frequency among friends and family or "members of the same social group ... [signals a type of] solidarity among speaker/listener" that does not exist in the standard English pattern "have+just+pp" (61).

Chapter 3, "I Intend to Try Some Other Part of the Worald': Evidence of SchwaEpenthesis in the Historical Letters of Irish Emigrants" by Persijn M. de Rijke, makes a really interesting journey across the diverse uses of the shwa-epenthesis and discusses a set of egodocuments from the still in progress Corpus of Irish English Correspondence (CORIECOR) which required "manual search." While the reader would expect some kind of daring conclusion from the large amount of data handled by the author, he prevents the fretful that he will not venture anything conclusive about the appearance of epenthesis in terms of rank, class, gender or religion. Partial conclusions are, however, still interesting: epenthesis is more frequent in mid- and late nineteenth century farmers' letters (91) and "occurs nearly exclusively" in the Ulster rural area (92). Yet, the author warns us, CORIECOR is still unfinished and it has a "northern bias" (92).

Dania Jovanna Bonnes also works with similar material from CORIECOR and 77 additional letters (from Eight letters from Ireland to John Forsythe the Emigrant with Some 
Others of Interest and a Genealogy of Four Generations of Forsythes in America, and Irish Immigrants in the Land of Canaan: Letters and Memoirs form Colonial and Revolutionary America, 1675-1815) and focuses on a diachronic study of "NEG/AUX Contraction in Eighteenth Century Irish English Emigrant Letters". She sets out to examine "differences with regard to the author's geographic origin, gender and social status" (109). In contrast with "Hickey's claim that the use of AUX-contracted 'll not is to be found copiously in historical texts of IrE, and his statement that a change to NEG contraction occurred in the nineteenth century, the fact that NEG won't is [widely] used in ... Ulster as well as the rest of Ireland, is an important finding" (120). But the author also breaks expectations as regards the conclusions of other authors such as Tagliamonte. All this is done with caution and the methodology considers, among other things, "the so-called Knockout contexts" (111), as well as the difficulties generated by the limited number of tokens, the often unidentifiable geographic origin of the letters and the biological sex or the social strata of their authors.

Pablo Ruano's chapter, half way between corpus linguistics and literary studies, proposes "A Corpus-Based Approach to Waiting for Godot's Stage Direction: A comparison between the French and the English Version". He justifies the study because "the systematicity with which some of these directions are used are not always easy to spot with the naked eye" (140) and because he attempts to find stylistic differences between the two texts. His study, limited by space and provisional in terms of an interpretation that relies on Lance S. Butler's and Góran Kjellmer ideas, claims that the English version (published 3 years after the French one) is stylistically more refined and not a self-translation from the original.

Following the growing trend to historicize Irish authors, José Francisco Fernández contends, in magnificent prose, that Samuel Beckett's Not I "contains traces of an Irish context" (170) against other traditional views that defend that the playwriter "only addressed eternal truths" (171). He agrees with Anthony Uhlmann that the context exists in Beckett's literary production, but that the connection with the external events has been purposely severed (172), which effects a "sense of abstraction" (Uhlmann 3) upon the readers. In addition to George O'Brien's list of Irish themes in Beckett's production, Fernández states that there are at least two elements that are "unmistakably Irish" (174): the character of the woman, "Mouth", in the play, and the setting, but he also finds reasons to suggest that the orphanage she attended was Irish (and Catholic), and that her discourse recalls the stereotypical "Irish banter" (175), and that the self-negation of identity (both personal and national) is doggedly Irish, like the murmurs of eerie voices in his other plays. All this in spite of Beckett's efforts to present a neutral play in a neutral language and accent, following T.S. Eliot's dictum about the impersonality of the author ("Tradition"). The focus on Mouth's disconnected speech calls attention to the very act of telling: the verbalization of a part of Beckett's childhood so detached from the author that it does not compromise his own emotions and cannot be sentimentalized. Nevertheless, Ireland is still there.

Gustavo A. Rodríguez Martín's chapter also moves in the same direction: contrary to the assumption that G. B. Shaw catered only for international audiences because of his Fenian ideology, the author argues that there is much of "Shaw's opinions on the political conflicts of Ireland" (189) in his historical plays and proposes an allegorical and symbolic study of Caesar and Cleopatra and Saint Joan. In addition to the grand themes that make the plays masterpieces, stage directions, setting, external texts such as Shaw's "Notes to Caesar and Cleopatra," characters depicting national archetypes (193) and Shavian anachronism (which is not precisely a drawback) all contribute along with textual phraseology and subtextual symbolism to allow the reader/audience connections with Shaw's views of Irish politics, among which is the notion that "nationalism is one of the blemishes of advanced human societies" (197). 
Daniel de Zubía Fernández, in his "Voices from War, a Privileged Fado" foregrounds armed confrontation areas from the Falklands to Afghanistan as locations "where people find, meet and define themselves and each other in any specific war" (209). The voices uttering those pretextual experiences share "a common narrative thread" (209) and may be read as a "fictionalized collective voice" (210) expressed through the "topos" of the homecoming. This is the case with the Portuguese António Lobo Antunes's Fado alexandrino and the Argentine of Irish descent Ronnie Quinn's El raro privilegio. Both novels use fact and fiction to provide a common voice and a shared sense of dislocation, although the setting for the first one is the Portuguese Colonial War (1961-74) between Portugal and its African colonies, and for the second the fight for the sovereignty of the Falkland Islands between the United Kingdom and Argentina (1982) seen through the eyes of an Irish descent. While the chapter is interesting in itself and surely perfect for a collection of essays on comparative literature (although a bit too long and repetitive at times), the connection with "voices and discourses in an Irish context" is slight and the two snippets connecting the protagonist of El raro privilegio to his ability as a translator and mediator between the Argentines and the British on pages 225-26 do not seem to fully justify its presence in the volume.

Teresa Casal's “A Century Apart: Intimacy, Love and Desire from James Joyce to Emma Donoghue", another wonderfully written chapter, compares the paralysis in Joyce's "The Dead" with the (apparent) "liberation" (political, linguistic, religious, social, sexual, emotional and otherwise) achieved by characters in Donoghue's "Speaking in Tongues". Casal's contention is that especially in the case of love, desire and intimacy, it is not always the case (237). To make her point, Casal relies on the works of the psychologists Carol Gilligan and Ziyad Narar and, after a magisterial presentation of the relationships between Gabriel and Gretta Conroy in "The Dead" and between Sylvia Dwyer and Lee Maloney in "Speaking in Tongues," she teaches the reader a lesson on intimacy and vulnerability to prove that "the twenty-first-century sophisticated coolness that seems to have replaced twentycentury notions of heroic self-sacrifice" has not changed the "longing for intimacy" (253-54): "self-immolation" has given way to "self-preservation" (255) in such a way that if "patriarchy is disabling for women as well as men" (256) in Joyce's story, Donoghue's "suggests that much as reciprocal desire may be consummated, a "mutually accepted fragility' remains a secret and 'frightening thought"' (256).

The last chapter, "Foreign Voices and the Troubles: Northern Irish Fiction in French, German and Spanish Translation" by Stephanie Schwerter, focuses on the difficulty of translating local culture into a different language. Errors, although at time diverting, are bound to occur. She chooses two popular Troubles novels to exemplify her point: Robert McLiam Wilson's Eureka Street (1996) and Colin Bateman's Divorcing Jack (1995) which, because they were published after the IRA ceasefire declaration (1994) allow the authors some humorous tone which, along with irony, parody and wordplay make translation even harder. The essayist draws on Lawrence Venuti's concepts of "domestication" and "foreignization" to discuss to what degree the three translations of Eureka Street, by Brice Matthieussent (French), Christa Schuenke (German) and Daniel Aguirre Oteiza (Spanish), find a solution to those difficulties in their respective cultures. Schwerter seems to favour the Spanish translation, probably because Aguirre Oteiza, being Basque, is more "sensitive to the story's violent context" (271) than the others. The three translations fail in appropriately transferring a reference to Seamus Heaney's "Blackberry Picking" but it is well known that if linguistic translation is usually difficult, cultural translation is too frequently almost impossible. The two translations of Divorcing Jack (there is as yet no Spanish version) suffer from the same limitations. Scherter calls the section "Struggling with the 'Untraslatable': The Difficulty of Transferring Telling Titles" as a word play based on phonetics does not easily find an appropriate equivalent in the target languages. Both Michel Lebrun (French) and 
Michael Kubiak (German) are forced to maintain the English original to keep an acceptably understandable version of the joke. No doubt "awareness of the local context is a key asset for any translator" (285). Yet, translators and Scherter seem to forget that, although apparently out of fashion, footnotes may be at times very useful.

All in all, the volume is a valuable contribution to Irish studies, covering linguistic, literary and translation lines that offer a wide diversity of interests raging from TV comedy to corpus studies and from the revision of canonical authors to the evaluation of translations. Perhaps the editors' attempt to cover such a broad spectrum may make the reader doubt about the appropriateness of the title itself but it must be conceded that to find an umbrella under which all chapter would fit is certainly no easy task.

\section{Works Cited}

Eliot, T.S. "Tradition and the Individual Talent". Perspecta 19 (1982): 36-42. JSTOR. www.jstor.org/stable/1567048. First published in The Egoist (Part I, September and Part II, November 1919).

José $\mathbf{M}^{\mathbf{a}}$ Tejedor-Cabrera is a Senior Lecturer at the University of Seville (Spain), is coeditor of the James Joyce Spanish Society Webpage, Iberjoyce and is co-translator of Anna Livia Plurabelle (Finnegans Wake I, viii) (1992), author of Guía a Dublineses de James Joyce (2002) and has co-edited Silverpowdered Olivetrees: Reading Joyce in Spain (2003), JoyceSbylia (2011) and Dreaming the Future: New Horizons / Old Barriers in 21st-Century Ireland (2011). Along with many articles and book-chapters on Joyce he has written about evaluation of Tandem programs (Peter Lang 2018). His latest publication is a chapter on Somerville\&Ross, Joyce and Modernism in Reimagining Irish literature and culture (TIR 2018).

jtejedor@us.es

Irishness on the Margins: Minority and Dissident Identities.

Edited by Pilar Villar-Argáiz.

London: Palgrave Macmillan, 2018. 290 pp.

ISBN: 978-3-319-74566-4

\section{Reviewer: Auxiliadora Pérez Vides (University of Huelva, Spain)}

Irishness on the Margins: Minority and Dissident Identities testifies to the prominent role of the editor, Pilar Villar-Argáiz, not only in the wider field of Irish studies, but most specifically, in the increasingly significant area of research about the multifarious processes of othering that have been present in Ireland historically, and their effects in the changing social landscape of the island. Her previous collections include relevant titles like Literary Visions of Multicultural Ireland (2014) and a special issue of Nordic Irish Studies devoted to "Discourses of Inclusion and Exclusion: Artistic Renderings of Marginal Identities in Ireland" (2016). Taken together, these three compilations of scholarly works offer a comprehensive analysis of how traditional hegemonic discourses collide with most recent transformations of Ireland's cultural order. In this new volume, as the editor makes clear, the notion of dissidence is incorporated to the critical analysis, so as to enhance "the interconnections normally established between minority voices and dissident voices" (3). Thus, her aim is to 
bring to the fore the "circles of resistance [that] tend to appear at the heart of minority groups which are discontented with their treatment by official standards" (3).

The academic rigour of Irishness on the Margins can be grasped at a first glance, for example, from its meticulous structural organisation. Indeed, the four parts in which it is divided comprise a balanced number of essays that truly bear out the most significant approaches from which the subjects of marginality and dissidence can be explored. Similarly, a foreword by Bryan Fanning - a leading academic figure in the Irish social sciences underscores the synthetic character of this edited volume, while also anticipating most of the major topics and genres under analysis. Besides, the reader will find quite helpful VillarArgaiz's introduction, where she provides a detailed list of the subjects covered in the essays and the main theoretical stands from which the contributors depart in their investigation. Her justification of the timeliness of the book is more than convincing, given the shifting social milieu, both in Ireland and internationally, in which it is published. In this context, she observes, "the essays gathered here remind us of the importance of 'rethinking' nationhood and belonging" (10).

Part I is appropriately entitled "Unearthing Dissidence in the Irish Past", as the works that it contains share a critical reading of how several key events in Ireland's contemporary history have taken a new expression in recent cultural and artistic manifestations. In the opening chapter, "Dragging up the Past: Subversive Performance of Gender and Sexual Identities in Traditional and Contemporary Irish Culture", Jeannine Woods establishes a thoughtful connection between the embodied practices of the merry wake tradition in Ireland and the performative, carnivalesque elements of the contemporary drag, epitomised by Panti Bliss. Thus, the author effectively demonstrates the challenge to categorical subjectivity that continues to inhabit Irish popular culture. A revision of the past is also the central part of the second essay, "The Wasted Island: Epistemic Friction in Revolutionary Ireland", written by John Keating. His main argument in the analysis of Eimar O'Duffy's much neglected novel is informed by several theoretical standpoints related to epistemic frictions and pluralism, which are brought to bear on the array of characters that appear in this text dealing with an alternative view of the 1916 Easter Rising. The third chapter, Katarzyna Ojrzyńska's "Dancing against the Tide: Reconstructing Irish Cultural Identity in Ken Loach's Jimmy's Hall", looks at the notion of socio-political resistance as represented by the subversive dancing bodies portrayed in this highly acclaimed film. The Foucauldian concept of "heterotopia" figures as a powerful critical lens through which the dissident space of the hall can be interpreted, while the critique of "heritage cinema" and the nostalgia it entails also occupies a focal position in the analysis.

In Part II, which is certainly the most cohesive one in the book, attention is paid to "Sexual Minorities and Dissident Gendered Subjects". The gender prism had to be inevitably present in this collection on marginality and it is perfectly signified in the three chapters selected for this part. The opening work is Katherine O'Donnell's powerful essay, entitled "Academics Becoming Activists: Reflections on Some Ethical Issues of the Justice for Magdalenes Campaign". This piece is a thorough, highly informative and moving description of the socio-historical background of Ireland's Magdalene Laundries as well as the events that have sustained the activism in favour of the victims of this system of incarceration of women considered sexually "deviant". The contributor's own personal experiences in the campaigns are combined here with engaging philosophical and ethical commentaries about the ongoing vulnerability of the Magdalenes and the full reparation that is still due to them. Much of this context resonates with what Miguel Ángel Benítez-Castro and Encarnación Hidalgo-Tenorio explore in the following chapter, "We Were Treated Very Badly, Treated like Slaves': A Critical Metaphor Analysis of the Magdalene Laundries Victims". In this illuminating approach to the trauma of Magdalene survivors from the perspective of discourse analysis, 
they study the conceptual metaphors used by these women when interviewed by the Justice for Magdalenes Research Group, demonstrating their internalisation of the marginal and shameful position to which they were allocated. And finally, "Abortion in Ireland: from Religious Marginalisation to State Recognition" by Edwige Nault explores the inconsistencies that still remain at stake in the present secularised Irish social order when it comes to the perception of crisis pregnancies and abortion. Written before the 2018 Eighth Amendment Referendum, this essay provides, nonetheless, an exhaustive examination of the different phases and events that have resulted in the declining influence of the Catholic Church and the more progressive attitude towards women's reproductive rights.

Part III consists of three enlightening chapters dealing with "Minority Voices in Irish Public Discourse" and it is inaugurated by Aidan O'Malley's work, "The Aestheticism of Minorities in The Crane Bag". Concentrating on the 1981 special issue of this relevant Irish cultural journal, O'Malley examines the different articles gathered by the editors at that time which delved into the experiences of a number of marginal communities, like homosexuals, Travellers, mentally ill people, etc. The author concludes that despite evident absences and fissures, The Crane Bag contributed to the long process of discussions about the accommodation of more liberal and inclusive attitudes on the island. Next, in "A Fragmented Minority: The Challenges to Public Institutionalisation of Islam in Ireland" Marie Violaine Louvet charts the presence of this religious minority in the Republic, while also tackling the articulation of Muslim identity. To this aim, she analyses the considerable role of organisations like Islamic Foundation of Ireland and Islamic Cultural Centre of Ireland for the integration of this marginalised, but indeed plural, community in the social body of the country. And the closing chapter is "The Cyber-Discourse of Inclusion and Marginalisation: A Critical Discourse Analysis of Muslims in Ireland and Northern Ireland on Twitter 20102014", by Abdul Halik Azeez and Carmen Aguilera-Carnerero. Their revealing work is methodologically based on corpus linguistics and it focuses on the discursive presence of Islamophobia and inter-religious connections in a substantial number of tweets posted in that five-year period.

Finally, Part IV moves towards "The Dissent of Minority Voices in Art" and it gathers three highly stimulating chapters. The first one, "Interculturalism and the Arts in PostConflict Northern Ireland" by Hèléne Alfaro-Hamayon, tackles the extent to which individual artists and community arts organisations have fostered a more inclusive attitude towards ethno-cultural diversity. After their case study of several art projects devoted to such issues, the authors observe that intercultural art practices figure as valuable mechanisms not only to fight racism and sectarianism but also, and most importantly, to usher in a more integrative response to difference. Then, in "Intercultural Harmony in Recent Irish Cinema: Moore Street Masala as a Case in Point" Rosa González-Casademont focuses on a short film by David O'Sullivan released in 2009. Starting with an in-depth taxonomy and contextualisation of the representation of immigrants and ethnic minorities in the media and on the screen, the author offers a stimulating analysis of a filmic text that, she concludes, proves the far-reaching possibilities of transcultural dialogue in present-day Ireland. And the final essay in this part is "Literature and Dissidence under Direct Provision: Melatu Okorie and Ifedinma Dimbo", by Sara Martín-Ruiz. Her brilliant analysis of two short stories by these Nigerian-born writers sheds some light on the injustices of the Direct Provision Centres in which asylum seekers have been placed since the implementation of this scheme in the late 1990s. However, the strongest point in this chapter is Martín-Ruiz's demonstrated appraisal of the literary value of their work within the contemporary panorama of the island.

On the whole, Irishness on the Margins stands as a major contribution to the field of Irish studies and an outstanding example of the many debates triggered by the old and new practices of othering that have taken place in Ireland. As for the outer reach of the volume, the 
essays gathered by Villar-Argáiz constitute a foremost aid for research on topics whose investigation is mandatory in the current state of affairs, both nationwide and on an international scale. Indeed, the pertinence and urgency of such discussions can be attested through the recommendation to "Check for updates" included on the top corner of the first page of all the essays. This element may be a technical, editorial device but it by no means encapsulates the high level of impact that strong academic works such as this bring for the unceasing process of articulation of Irish identities.

\title{
Works Cited
}

Villar Argáiz, Pilar, ed. Literary Visions of Multicultural Ireland: The Immigrant in Contemporary Irish Literature. Manchester: Manchester University Press, 2014. (2016).

Auxiliadora Pérez Vides is a Senior Lecturer at the Department of English, University of Huelva, Spain. She has conducted extensive research on the intersection of gender, nation, family and social history in contemporary Ireland. Her publications include Sólo ellas: familia y feminismo en la novela irlandesa contemporánea (2003) and the co-edition of Espacios de Género (2005), Single Motherhood in Twentieth-Century Ireland (2006), Gendering Citizenship and Globalization (2011), Experiencing Gender (2015) and Words of Crisis/ Crisis of Words (2016). Her current research interests focus on the cultural manifestations of Ireland's Magdalene Laundries and John Banville's crime fiction.

mariaa.perez@dfing.uhu.es

\author{
Un Almuerzo Literario y Otros Cuentos. \\ Éilís Ní Dhuibhne. \\ Translated with introduction and notes by Luz Mar González-Arias \\ Oviedo: KRK Ediciones, 2018. 141 pp. \\ ISBN: 978-84-8367-600-4
}

Reviewer: Lluïsa Schlesier Corrales (Autonoma University Barcelona)

Un almuerzo literario y otros cuentos contains Éilís Ní Dhuibhne's first translated short stories into Spanish. Her introduction to Spanish readers could not have taken place at a more propitious moment: 2018 has been a pivotal year for feminism both in Spain and in Ireland. In Spain on 8 March, women flooded the streets of the country's main cities like a purple wave; a historic strike and huge demonstrations brought the country to a halt and forced it to listen to women's demands for equal rights and an end to gender-based violence. In Ireland on 25 May, the repeal of the Eighth Amendment (removing the constitutional ban on abortion) established a new landmark in female rights.

The three short stories that make up this collection revolve around female characters and the experience of being a woman in a male-dominated society. The publication of this beautifully bound little book is in itself a revindication of the importance of women writers in the Irish tradition, a tradition in which, as González-Arias comments in her introduction, they have been neglected for a long time and still remain practically invisible outside Ireland (12). 
Éilís Ní Dhuibhne (b. 1954, Dublin) is one of the most interesting and intelligent voices of her generation, as González-Arias expresses it (12). Although she is recognised as a master of the short story, Ní Dhuibhne has also written "variously as a folklorist, dramatist, ... novelist, editor, literary historian and - under the pseudonym Elizabeth O'Hara - children's author", as Anne Fogarty informs us in the preface of Midwife to the Fairies (ix). In addition, growing up in a bi-lingual home, Ní Dhuibhne writes her work both in English and in Irish. Among the many awards that Ní Dhuibhne has won (The Bisto Book of the Year Award; the Reader's Association of Ireland Awards; the Stewart Parker Award for Drama; the Butler Award for Prose; several Oireachtas awards; the Henessy Hall of Fame award for lifetime achievement and a shortlisting for the Orange Prize for Fiction), the most noteworthy is the Irish PEN Award for Outstanding Contribution to Irish Literature (2015), as recipients to-date have mostly been men.

The three stories that make up Almuerzo are "Un almuerzo literario" ("A Literary Lunch, published in 2012), "¡Bota salta y bota por de Valera!" ("Wuff Wuff Wuff for de Valera", published first in 2001 and again in 2003) and "Los pavos reales" ("Peacocks", 2003). Each of these has been wonderfully translated by Dr Luz Mar González-Arias, senior lecturer of English Philology in the Department of English, French and German Philology at the University of Oviedo. González-Arias also provides the concise yet highly informative introduction, in which she offers a brief overview of each story and reviews the historical and cultural context of which they form part. This, I find, greatly facilitates the understanding of these stories for those unfamiliar with Irish culture or Ní Dhuibhne's work, making them available to a far larger Spanish readership. Additionally, González-Arias comments on the challenges in translating each story and justifies a number of her choices, illustrating how she bridged the gap between the Irish and Spanish cultures. Each of the stories is accompanied by a series of explanatory notes that, without ever being overwhelming, clarify cultural concepts that might be unknown to the non-specialist Spanish reader and which enable a far fuller experience of the text. In this review, I have chosen to focus precisely on this aspect, the translation of the stories, rather than on their content, thus providing my impressions primarily as a Spanish reader of these texts.

Set in the Dublin of the Celtic Tiger years, "Un almuerzo literario" "explores the power mechanisms and gender dynamics in the world of cultural organisations and literary awards" (González-Arias, 14-15). In the story, the members of a literary committee are having lunch at a prominent restaurant, after voting which writers will receive the committee's latest bursary. It soon becomes evident, however, that it is the committee leader, Alan King, who alone holds almost tyrannical power over the Dublin literary scene. Francie Briody, an unsuccessful middle-aged writer, seethes at the thought that his dream of becoming a full-time writer depends exclusively on Alan King's approval. Pam, the newest member on the committee, after unsuccessfully trying to intercede in Francie's favour, unknowingly irritates Alan by expressing her concern that they might have elected the wrong people for the bursary. To my mind, González-Arias has excellently rendered the essential fabric of "A Literary Lunch" through her translation: the puns, the premonitory images that foreshadow the ending of the story, the dry humour, all are successfully accounted for in the Spanish version. Two examples: Pam, Mary and Jane discuss the latest production of Ibsen's A Doll's House at the Abbey Theatre in a witty and snappy manner that is perfectly reflected in the Spanish. The same is true for the humorous confusion that ensues when the women, who can't really hear what the men are saying (as they have been strategically exiled to opposite ends of the table), realise that the men have ordered expensive starters, while they only have a soup. The brilliance of these ironic exchanges is wonderfully caught in this version, and so I would certainly say that González-Arias has fully succeeded in overcoming one of the main challenges that she identifies (18-19) in translating this particular story. The 
second challenge that she remarks on, recreating Dublin's particular atmosphere during the years of the Celtic Tiger, is amply overcome through the notes González-Arias provides both in the introduction and throughout the story. Indeed, through the immediacy and effectiveness of this version, I would also suggest that the Spanish reader might very well connect the unbridled consumerism and carefree spending on evidence here with the pre-crisis years in Spain itself, which in the collective memory are sometimes thought of as a time of serenity, growth and abundance. Additionally, each character's particular voice has been most successfully rendered: Alan's rather contemptuous tone is easily distinguished from Pam's more hesitant words, as well as from Francie's cynical brooding. Likewise, certain minute alterations, such as changing an Aldi bag for a Lidl bag, far from affecting the content of the story actually bring the text much closer to Spanish readers and facilitate their fuller identification with the text.

The second story in Almuerzo, "iBota salta y bota por de Valera!”, is set in the midtwentieth century and tells the story of twin-sisters Pauline and the narrator, whose name we never discover. Coming from a poor, working-class family, the two sisters fight their way to Trinity College, wishing to break free from the mundane futures that would otherwise be set out for them. Nevertheless, Pauline's aspirations are dashed as she becomes pregnant and cannot take on the costs of having an abortion in England. While Pauline spends the rest of her life taking care of her child, born with a severe mental condition, the narrator marries into a wealthy family and the sisters' lives drift apart forever. The story is told in the first person by the narrator and her discourse consists of a constant comparison between her rather perfect life and Pauline's completely unglamorous existence, which the narrator disdains and blames Pauline for. It is the faithful reproduction of the narrator's speech that González-Arias sees as her greatest challenge (26). The narrator's working-class upbringing, on the one hand, and her acquired upper-class status, on the other, render her speech inconsistent as she attempts to speak in a sophisticated manner, while constantly resorting to colloquial, sometimes even vulgar, language, as with the following: "We're doing a safari in Zimbabwe and Emma loves animals and ecology and all that crap", translated as "Nos vamos de safari a Zimbabue y Emma adora los animales y la ecología y toda esa mierda" (71) or "We got [the house] when his mother finally kicked the bucket last year", rendered as "Nos la quedamos cuando su madre finalmente la palmó el año pasado" (89). Another added difficulty to the translation of this text is the use, at a certain point, that Pauline makes of an expression in Hiberno-English: "I'm after saying that already". González-Arias indicates that she opted to translate this expression by creating a fictitious Spanish dialect, so as not to link the text to any particular area of the Iberian Peninsula, and delivered it thus: "eso ya me lo acabo de decir" (80). This, to a Spanish reader will certainly sound unfamiliar and possibly even incongruous, however, it is precisely what makes the translation successful, as it presumably will provoke in the reader the same estranging effect that Pauline's sentence has on her professor and fellow students at Trinity. Likewise, as in the previous story, there are certain changes from the original to the translation, which, as I see it, help the Spanish reader to remain immersed in the text without the particularities of the original intruding into the textual experience, as for instance the translation of nursery rhymes ("“'In and out goes Mary Bluebell'. 'Plainy packet a rinso"” rendered in Spanish as "Al pasar la barca, me dijo el lechero'. 'Tengo una pelota que salta y requetebota", (75)), or the translation of supermarket names (Superquinn becomes Aldi and Dunnes Stores, Carrefour). Once again, this strategy allows González-Arias to succeed in overcoming these challenges and results in a text fully consistent with the effect of the original. The narrator's haughty tone and her phony-sophisticated speech have been delivered with precision and the impression - perfectly perceptible in the original text - that we are facing a narrator who is "selfish, shallow and lacking in solidarity" (González-Arias 26) remains intact throughout the translation. 
The third and final story in the collection, "Los pavos reales", focuses on the complex themes of mother-daughter relationships, sexual awakening and anorexia. Set in Spain, in two different time spans, this text tells the story of Anita, her partner Marcus and her daughter Aisling on a trip to Asturias. There, the family stays in a hotel in which Anita had worked as a maid twenty years earlier, when she was the same age her daughter is now. As Anita struggles to understand and deal with Aisling's anorexia as well as her stubborn character and complicated moods, she also recalls her own dalliance with anorexia in her teenage years, her improbable friendship with Sharon, another maid at the hotel, and her first romantic relationship with Juan, all of which took place during those earlier years in Spain. The hardest challenge in translating "Peacocks" might have been to maintain the impression that the protagonist is an outsider, as all the Irish geographical and cultural elements present in the two first stories are no longer there. González-Arias explains how, in order to maintain Anita's outsider gaze, for instance, she avoided using the specific Spanish terms for the ritual of pouring cider, as Anita would not be familiar with this. Similarly, the narrator's comment that "dinnertime in Spain is ten o'clock", delivered as "la hora de la cena en España es a las diez de la noche" (102), might seem unnecessary to a Spanish reader, but it reinforces the impression that the story is told from a foreigner's perspective. Another similar instance occurs when, at a given point, Anita accidentally speaks to a taxi driver in English, and then corrects herself in Spanish: "Nothing,' she says. "Nada". By leaving the first "nothing" untranslated, González-Arias once more exposes the clash of the two cultures: "Nothing responde -. Nada" (138). Reading the text in Spanish, I never once doubted that I was learning about the story of three tourists visiting Asturias, discovering the different settings exactly as an outsider would.

In short, I believe that the reader will find Almuerzo to be an excellent translation of a unique work. González-Arias has skilfully managed to maintain the spirit of the original texts in her translation. In particular, apart from bringing Irish and Spanish cultures closer through the skilful approximation of Irish culture to Spanish readers (specialist and non-specialist alike), this translation also puts the focus on a writer whose name, despite her brilliant trajectory, is not as well-known as that of her male peers. This translation, consequently, is crucial when it comes to challenging the traditional male-dominated literary canon and in bringing light to those voices that have been ignored for too long: it is a celebration of female authorship and all that this implies, such as a different perspective, a different style and even a different vision of Ireland.

\section{Works Cited}

Éilís Ní Dhuibhne. Midwife to the Fairies. New and Selected Stories. Cork: Attic Press, 2007 (2003).

Lluïsa Schlesier Corrales is a $\mathrm{PhD}$ candidate at the Universitat Autònoma Barcelona (Spain). She holds a BA in English Studies (with Honours) and an MA in Advanced English Studies. Her research focuses on the representation of the contemporary Irish working class in the novels of Roddy Doyle.

tjekker2@gmail.com 
Desnudo.

Nuala Ní Chonchúir.

Translated by Máximo Aláez Corral.

Oviedo: KRK, 2017. 316 pp.

ISBN: 978-84-8367-585-4

\section{Reviewer: Antonio Rivero Taravillo}

Among the many Irish writers of her generation, Nuala Ní Chonchúir (Dublin, 1970) is one of the most interesting and well worth reading. She is the author of five books of poetry, three collections of short stories and four novels. The most recent of these is Becoming Belle (2018), now under her real and first name, Nuala O'Connor. She was born and raised a Dubliner, but attended a Gaelscoil and learnt and fell in love with an teanga, using from then on the Irish version of her name. Her previous novel was Miss Emily (2015) about Emily Dickinson and her Irish maid. Dermot Bolger has written about this gem of a book: "Nuala O'Connor's luminous prose has long been one of Ireland's most treasured literary secrets. Now through her superb evocation of 19th century Amherst, an international audience is likely to be held rapt by the sparse lyricism and exactitude of O'Connor's writing".

Contemporary Irish literature can claim an impressive number of gifted authors in all genres and in both languages, Irish and English. As regards poetry, and poetry in Irish, and poetry in Irish written by women, to be more precise, this has proved to be very successful, with names such as Nuala Ní Dhomhnaill, Celia de Fréine, Ailbhe Ní Ghearbhuigh or Doireann Ní Ghríofa, among many others. Ní Chónchúir has published a bilingual collection, Tatú/Tattoo to great acclaim. She translated her own poems and no tomfoolery was that at all since Nuala holds a BA in Irish from Trinity College Dublin and a master's degree in Translation Studies (Irish/English) from Dublin City University. She prefers to speak of versions, and this is what they are, with changes and delicate touches in a negotiation with rhythm and meaning.

Therefore, as can be gathered from the above, translation is important for her (and for all who are stubborn enough to keep writing in the old vernacular tongue). But the writer must earn her living and pay bills, so she uses English in her books. Her second collection of short stories (Nude, 2009) has just been translated into Spanish. It is the first time her work is available for Spanish-speaking readers. The translator is Máximo Aláez Corral, an artist and lecturer at the University of Oviedo in Asturias, interested in gender studies as the two books of his own, no doubt, prove: Cuerpos reales/Cuerpos figurados (2011) and Violencias simbólicas y otras agresiones corporales en la fotografía contemporánea realizada por mujeres: de la mirada masculina a la acción crítica (2018).

He has done an excellent job in his introduction, focusing on paintings (there are many of them in the stories), the difference between a nude and nakedness, drinking, sex, and underlining the many literary and artistic references that occur: Wilde, Picasso, Louis Le Brocquy, Frida Kahlo... (This Mexican painter, by the way, appeared in one of Ní Chonchúir's poems: "Frida Kahlo Visits Ballinasloe" The Juno Charm, 2011). Works of art inspire her, mingled with desire and frustration. In that same book she included the poem " $\mathrm{A}$ Cézanne Nude", using again the word title of this one, a handful of stories in which there is, once again, one called "Roy Liechtenstein's Nudes in a Mirror: We Are Not Fake!". At the beginning of the book Ní Chonchúir quotes John Berger: "Nudity is a form of dress" (Ways of Seeing). But Berger also stated there that "To be naked is to be oneself. To be nude is to be seen naked by others and yet not recognised for oneself". Translating is undressing a text and redressing so that it can be recognized for others and be itself again. 
Aláez Corral's rendering of Ní Chonchúir's prose in Spanish is very good too. There are a few mistakes, though, that should be corrected in a second edition if the opportunity arises. Aláez Corral states in his introduction ("La desnudez según Nuala Ní Chonchúir") that the author extracts from poetry a special "attention to language and the selection of specific words". But there are a few words that, alas, he has not chosen well himself: In "Madonna Irlanda" (same title in English) and in "Pesca nocturna" ("Night Fishing") he uses "whisky" instead of "whiskey", which would be more appropriate to keep the Irish flavor (or was it someone at the publishing house at some step through the editing process who changed it?).

To be fair, he has done his best to keep the colloquial English as spoken in Ireland that some of the dialogues show. It was not easy at all to render the language of "Una princesa Amarna del Norte" ("An Amarna Princess Up North"), where "why I done it" becomes the plainer and standard "por qué lo había hecho"; the Hiberno-English, almost Kiltartanian "they says to me" is in the translation just a dull "me dicen". "I didn't go to no art school" is then rendered as the correct and perfectly educated Castilian "no he ido a ninguna escuela de Arte". Nevertheless, "as it happens" is in Spanish the fresh "ya ves tú", as said by any corner boy.

In "Antes de perder la maleta, pero sobre todo después de haberla perdido" ("Before Losing the Valise, but Mostly After") he translates "excited" as "excitada", which is a common mistake (the real meaning is "hacer ilusión", "estar entusiasmado", etc.). "Anxiety" is translated as "ansiedad" in another story, and not, as it happens to be, "angustia" (as Harold Bloom would be happy to explain using his term "anxiety of influence", which does not mean "willingness for influence", but the anguish it provokes). A shade of meaning as it may be, the grossest error of the book is translating a few pages later "conductor" as "conductor" (no conundrum intended). As applied to trains, which is the case here, the English "conductor" is actually the Spanish "revisor", the person who collects tickets. "Conductor", in Spanish, means "driver", "engine driver". In "Xavier", a story set in Barcelona, it is to be wondered how many pints of plain the translator had drunk at "The Ramblers" before translating the name of the public house as "Los Rambleros". Always fond of a drop and a good pun, Flann O'Brien/Myles na Gopaleen would have laughed at this, yer man would have loved this wan. This is really funny, for a footnote states: "“The Ramblers" in the original". It is well known that the Ramblas is Barcelona's main thoroughfare. But Rambler does not refer to that, meaning "wanderer" or "roamer". Dublin City Ramblers is, by the way, the name of an Irish folk band noted by its Republican repertoire as well as nostalgic ballads the sort of "The Rare Ould Times". Please note that these are but very little objections to the overall sound, accurate and brilliant translation.

In "Writing the Naked Body: Sex and Nudity in Nuala Ní Chonchúir's Nude" (Estudios Irlandeses 11 (2016): 1-11), Aláez Corral wrote about this collection of stories: "Ní Chonchúir boldly explores the possibilities of representing/narrating the naked body (both male and female), in tight connection with a preference for the sexual reading of the body as it is gazed upon by a far from innocent gendered 'gaze"". He is right: painters and models, erotic vision and the vision of Eros, voyeurism and the yearning for freedom and ambiguous relationships make up a challenging and rewarding collection of stories not to be missed by one of the finest Irish writers of today.

Antonio Rivero Taravillo was born in Melilla (Spain) in 1963. After studying Irish, he has translated several books, including Flann O'Brien's only novel in Irish An Béal Bocht (La boca pobre) in 1989 and Liam O'Flaherty's Dúil (Deseo, 2012). He has published six volumes and a pamphlet of poetry, two novels, two awarded biographies, two collections of aphorisms, three travel books and two scores of literary translations. He has also translated an 
anthology of early Irish lyrics, W.B. Yeats's Collected Poems, and novels by Jonathan Swift and Jamie O’Neill.

antonioriverotaravillo@gmail.com 